\title{
Manganese-It Turns Iron Into Steel (and Does So Much More)
}

As part of a broad mission to conduct research and provide information on nonfuel mineral resources, the U.S. Geological Survey (USGS) supports science to understand

- How and where manganese resources form and concentrate in the Earth's crust

- How manganese resources interact with the environment to affect human and ecosystem health

- Trends in the supply of and demand for manganese in the domestic and international markets

- Where undiscovered sources of manganese might be found

Why is this information important? Read on to learn about manganese and the important role it plays in the national economy, in national security, and in the lives of Americans every day.

Without manganese, there would be no steel.

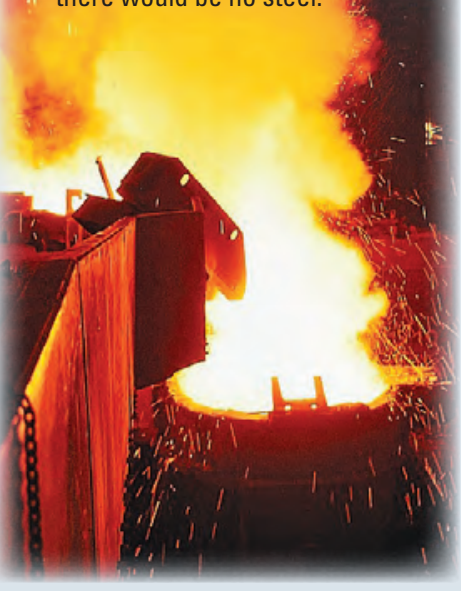

What is steel made from? Many people would correctly respond that steel is made of iron. Far fewer know that it is also made of manganese. Although the amount of manganese used to make a ton of steel is small, it is just as essential as iron to produce this fundamental building block of modern industrial societies. Put in simplest terms - you can't make steel without manganese. Domestic consumption of manganese is about 500,000 metric tons each year, predominantly by the steel industry. The United States is totally reliant on imports for this amount of manganese. Manganese is a common ferrous metal with atomic weight of 25 and the chemical symbol Mn. It constitutes roughly 0.1 percent of the Earth's crust, making it the 12th most abundant element. Its early uses were limited largely to pigments and oxidants in chemical processes and experiments, but the significance of manganese to human societies exploded with the development of modern steelmaking technology in the $1860 \mathrm{~s}$. Because manganese is essential and irreplaceable in steelmaking and its global mining industry is dominated by just a few nations, it is considered one of the most critical mineral commodities for the United States.

\section{How Do We Use Manganese?}

As much as 90 percent of manganese consumption, both in the United States and globally, is accounted for by the steel industry. Manganese removes oxygen and sulfur when iron ore (an iron and oxygen compound) is converted into iron. It also is an essential alloy that helps convert iron into steel. As an alloy it decreases the brittleness of steel and imparts strength. The amount of manganese used per ton of steel is rather small, ranging from 6 to 9 kilograms. About 30 percent of that is used during refinement of iron ore, and the remaining 70 percent is used as an alloy in the final steel product. Manganese is used also as an alloy with metals such as aluminum and copper. Important nonmetallurgical uses include battery cathodes, soft ferrites used in electronics, micronutrients found in fertilizers and animal feed, water treatment chemicals, and other chemicals such as those used as a colorant for automobile undercoat paints, bricks, frits, glass, textiles, and tiles. The product "manganese violet" is used for the coloration of plastics, powder coatings, artist glazes, and cosmetics.

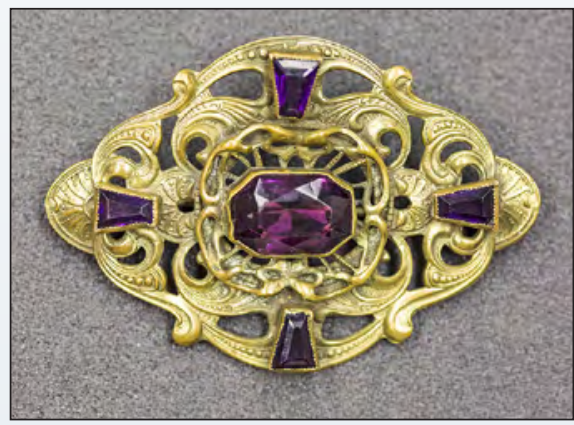

Ancient Egyptians and Romans used pyrolusite, a mineral of manganese dioxide, to control the color of glass. Small additions decolorized glass by removing the greenish yellow discoloration caused by iron impurities, whereas larger additions colored the glass pink, purple, or black. Manganese dioxide is still used today as a colorant. Photo by Scott Jackson, USGS.

\section{Where Does Manganese Come From?}

Elemental manganese readily combines with oxygen, carbon, and silicon to form a long list of manganese minerals. Manganese ores generally contain 25 to 45 percent manganese, mostly in oxide (or hydroxide) and carbonate minerals. Such ores are widespread, but most of the world's supply is from a small number of manganese mining districts. Most manganese ores are extensive layers of manganese-rich sedimentary rocks that formed in ancient oceans under specialized conditions when changes in the oxidation state of ocean water first caused high concentrations of dissolved manganese and later precipitated various manganese minerals that became concentrated on the seabed. These layers are now found within the bedrock of continents. Some are considered "primary ore," because they are rich enough in manganese to be of ore grade. Others are "secondary ore"-zones where the original manganese content of the sediments has been naturally enriched by younger geologic processes. Nearly all manganese ores are beneficiated near the mine sites to improve the manganese grade before further processing. Most also are smelted to form the alloys ferromanganese and silicomanganese. It is these alloys, rather than manganese ore itself, which are used in most metallurgical applications. An additional potential source of manganese is the vast layer of ferromanganese nodules that cover the deep seabed of many of the world's oceans. These potato-sized nodules are currently the target of exploration and research by 13 organizations, aimed at economic development mostly focused on the equatorial Pacific Ocean. Should production of these nodules prove technically, economically, and legally viable, they could provide the world with a major new source of manganese for a very long time. 


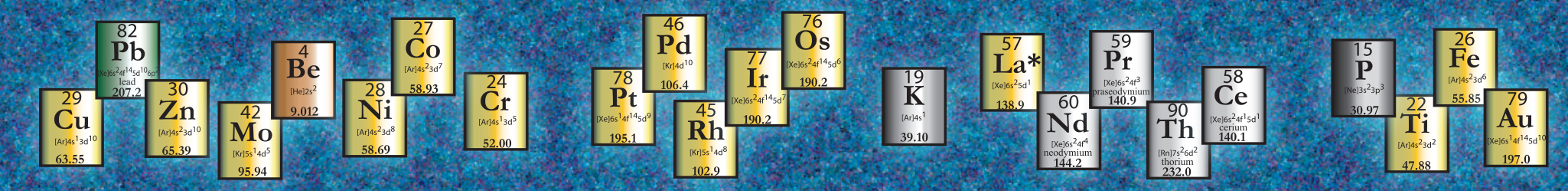

\section{Worldwide Supply of and Demand for Manganese}

In 2011, 70 percent of world manganese ore was produced by just four countries: in decreasing order of production, they were South Africa, Australia, China, and Gabon. Ninety percent of proven manganese reserves are also in these four countries, plus Brazil and Ukraine. The United States has no manganese reserves, as is the case for many other industrialized countries, especially in Europe. All manganese ore consumed in the United States is imported. From 2008 to 2011, the primary sources of ore were Gabon (61 percent), Australia (21 percent), South Africa (7 percent), and Brazil (5 percent). Although there are two manganese ferroalloy and three manganese chemical producers in the United States, the country still

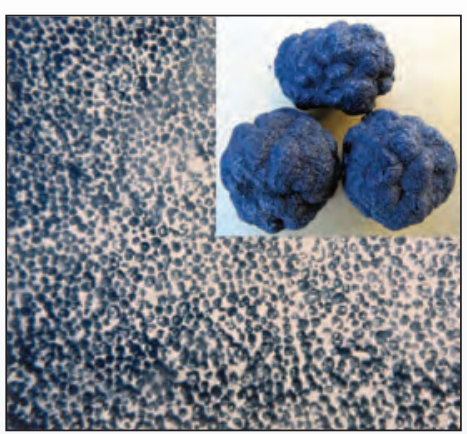

A dense carpet of naturally occurring ferromanganese nodules on the seabed off Johnston Island within the U.S. Exclusive Economic Zone near Hawaii. Field of view is about 4 square meters. Inset shows individual nodules, each about 3 centimeters in diameter, from the equatorial Pacific Ocean. Photos by James Hein, USGS. requires large imports of manganese alloys, chemicals, and metal to meet its consumption needs. From 2008 to 2011, ferromanganese imports were predominantly from South Africa (51 percent), China (13 percent), Ukraine (8 percent), and the Republic of Korea (7 percent). Silicomanganese was imported mostly from South Africa (41 percent), Georgia (23 percent), Norway (14 percent), and Australia (11 percent). Demand for manganese historically closely follows steel production and is expected to do so in the future. The annual growth rate for steel has typically been 1 to 2 percent in the United States.

\section{Mid you know... Manganese is widely used as an alloy with aluminum, to which
Most beverage cans consist of about 1.5 percent manganese.}

\section{How Do We Ensure Adequate Supplies of Manganese for the Future?}

Although the total reserves of the world are adequate to meet foreseeable demand, there has long been a concern in the United States, because of its total import reliance for manganese ore, for a continued manganese supply in light of possible political or military disruptions of production or supply chains. Although there are large resources of manganese-enriched rock in the United States, mostly in Maine and Minnesota, their manganese content is substantially below manganese ores readily available from other parts of the world so they are presently uneconomic to mine. Globally, there is no shortage of manganese ore. Land-based manganese deposits are dominated by the great Kalahari manganese district of South Africa, which accounts for roughly 70 percent of known manganese resources of the world (reserves plus identified material that has yet to be fully proven to be economic). As a result, South Africa is expected to continue to play a dominant role in global manganese supply well into the future. However, should deep seabed mining become economic, the sources of manganese ore could significantly shift from land to ocean. The estimated resource of manganese nodules dwarfs land-based resources and could greatly diversify manganese sources for the United States and other countries. In addition to the resources of the deep seabed, largely in international waters, substantial seabed manganese

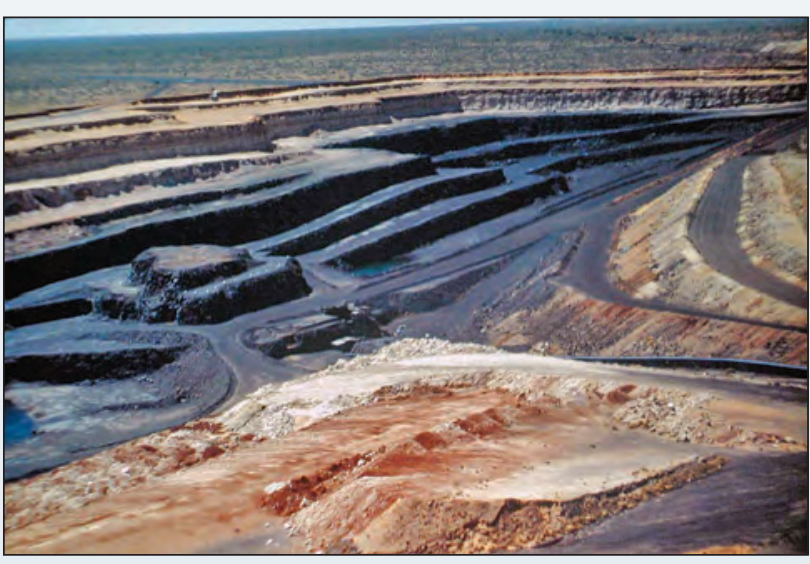

Mamatwan manganese mine in the Kalahari District of South Africa. A thick layer of manganese ore is mined from this open pit mine. The mine benches follow the sedimentary layering of the ore body. Photo by William Cannon, USGS. resources might be developed within the U.S. Exclusive Economic Zone, which would be entirely under United States jurisdiction.

\section{For More Information}

- On production and consumption of manganese: http://minerals.usgs.gov/minerals/pubs/ commodity/manganese/index.html

The USGS Mineral Resources Program is the principal Federal provider of research and information on manganese and other nonfuel mineral resources.
For more information, please contact:

Mineral Resources Program Coordinator

U.S. Geological Survey

913 National Center

Reston, VA 20192

Telephone: 703-648-6100

Fax: 703-648-6057

Email: minerals@usgs.gov

Home page: http://minerals.usgs.gov 